IOANA ALEXANDRA LIONTE

\title{
THE ENGLISH TRANSLATION OF MIHAI EMINESCU'S POETRY
}

Part 1

1. World literature: towards an axiological shift in literary studies

The contemporary cultural scaffolding (manifesting itself under different sociological, political, anthropological, artistic dynamics) is the result of a paradigmatic shift that occurred within the identity-alterity dialectic, therefore allowing for (and even fervently encouraging) a programmatic intercultural flexibility and openness. Literary studies were no exception in this respect. Therefore, the crystallisation of the "world literature" concept into both discourse and method circumscribes the most recent epistemological framework of cultural and literary analysis, facilitating a transnational (post-national, even) analysis of literature viewed as a network structure rather than as a hierarchical construct or as a centre-periphery type of dynamic. Although the world literature concept has only recently transformed itself into a paramount framework of literary studies, the notion is far from being novel. We say this because in 1827 , in a conversation with his disciple Johann Peter Eckermann, Goethe coins the term Weltliteratur by saying the following:

I am more and more convinced that poetry is the universal possession of mankind, revealing itself everywhere and at all times in hundreds and hundreds of men... I therefore like to take a look around at foreign nations, and I advise everyone to do the same. National literature is now a rather unmeaning term; the epoch of world literature is at hand, and everyone must strive to hasten its approach ${ }^{1}$.

In hindsight, Goethe's words anticipated not only the formation of a new cultural consciousness (that would translate into a literary perspective) but also the twilight of national literatures that dominated the $19^{\text {th }}$ century. Goethe's Weltliteratur is defined as a cultural exchange network, a trade in ideas on the literary market, to which every nation contributes with its own products. Therefore, speaking to his disciple about the fall of national literatures and the rise of a world literature, Goethe anticipated the development of the Weltiteratur notion as both a conceptual space and a cartography method for the cultural and literary geography.

As we have previously stated, two centuries later we witness a new paradigm in the field of literary studies, whose stake is to detach itself from the nationalist rhetoric of the $19^{\text {th }}$ century and from the centre-periphery type of literary axiology

\footnotetext{
${ }^{1}$ Johann Peter Eckermann, Gespräche mit Goethe in den letzten Jahren seines Lebens, apud David Damrosch, What is World Literature, New Jersey, Princeton University Press, 2003, p. 1.
} 
and analysis that has polarized, until recently, the topography of the literary universe. World literature is no longer regarded as the sum of national literatures, each legitimized by its own literary canon, but rather as a network. A good number of theoretical contributions striving to address the issue of what exactly world literature is started laying the foundation of a solid theoretical framework and resulted in the creation of new research optics and analysis instruments in the literary field. Authors such as Pascale Casanova, David Damrosch, Emily Apter, Harold Bloom, Franco Moretti or Immanuel Wallerstein have not only relevantly addressed the issue (directly or indirectly) but also managed to assess, define, detail the theoretical framework based upon a valid, realistic definition of world literature. That does not entail, however, the prevalence of a unitary perspective, for world literature itself is a fluid concept. To that effect, debates have surged regarding the characteristics of this construct, theoretical antagonisms being identifiable even at a methodological level, since the research methods themselves are interdisciplinary and differ from one another (Casanova, for instance, uses economic metaphors, whereas other theorists draw their research angles from organicist theories or from cognitive sciences). Overall, the attempts to define or to quantify the universal have resulted in interesting premises and answers to the question: What is world literature? To that, Casanova's World Republic of Letters ${ }^{2}$, for example, offers a detailed presentation of the institutionalised cultural exchange that takes place between nations, revealing an intricate mechanism of literary production, dissemination and recognition and exemplifying it through a centreperiphery type of dynamic (her theoretical system was qualified as Gallocentric). David Damrosch, on the other hand, allows for more than one definition of world literature: "as an established body of classics, as an evolving canon of masterpieces, as multiple windows on the world"3.

However, the purpose of this paper does not allow for more than a brief, introductory account of the aforementioned concept that will serve as premise for more specific research, for its aim is to investigate an illustrative case for the issue of Romanian literature theorized within the larger framework of world literature. We will begin by noticing that Romanian literary studies did not fail to align themselves to the recent epistemological framework that privileges the study of world literature as a transnational way of envisaging literary texts (observed dialogically, in circulation, as part of a network rather than of a hierarchy).

The recent debates striving to circumscribe world literature and to evaluate the national context as part of an international system rather than opposed to it are, by far, not only the result of a purely theoretical interest in the most recent literary developments but a programmatic reassessment of national literature that marks the end of the classical canonical paradigm in favour of an intersectional approach.

\footnotetext{
${ }^{2}$ Pascale Casanova, The World Republic of Letters. Translated by M. B. DeBevoise, Cambridge, Harvard University Press, 2004.

${ }^{3}$ David Damrosch, What is World Literature, p. 15.
} 
One of the most recent endeavours that pointedly marked this paradigmatic shift in literary studies is a collective volume entitled Romanian Literature as World Literaturethat epitomises the Romanian literary critics and historians' attempts to rethink Romanian literature in terms of world literature in order to change the research angle, as "the Romanian case study goes to show that, when reframed intersectionally, as nodal subsystems of a vaster, ever-fluid continuum, so-called 'marginal', 'minor', or 'small' literatures acquire an unforeseen and unorthodox centrality"4.

\section{The greatest unknown universal poet: the Eminescu paradox}

Countless and countless debates, articles and volume chapters attempted to describe, explain and eventually solve the issue of Mihai Eminescu's exportability in terms of a cultural product relevant to the foreign public. The subjects addressed while tackling this seemingly unresolved problem vary from mythicising the national poet, which functioned as a trademark of the national legitimizing process, to the lack of cultural branding know-how, to the translatability issue regarding Eminescu's poetry (that is seldomly placed within the ranks of the "brilliant untranslatables") and the quality of existing translations. Literary researchers, historians and translators all approached the aforementioned issue (among the authors that dedicated studies to the subject we count Ioana Bot, Iulian Costache, Andrei Terian, Lucian Boia, etc.), some of them concluding that Eminescu is bound to remain a dictionary author and an insular national icon, others still believing that in light of well-thought, systematic cultural strategies and better translations, Eminescu has a chance of obtaining the recognition and place in international culture that are proportional to his value.

When it comes to the issue of Mihai Eminescu as a national myth, we tend to agree with the rhetorical observation that Andrei Terian makes in his study Mihai Eminescu: From National Mythology to the World Pantheon: what indeed "could be more remote from world literature" than national poets? The myth-making process that transformed Eminescu into a polished, edulcorated, typically messianic image that no longer has to do with his actual work but with the national aspirations and cultural complexes with which he was branded is extremely relevant to the question of his exportability, as it goes to show that coining the argument of a culture and an author's originality in "an ethnic essence" results in the creation of an indigenous monolith "whose authentic authority is hardly available to the "allogeneic". In other words, the image Eminescu-the national poet may have served its purposes in a national context (in different time periods

\footnotetext{
${ }^{4}$ Mircea Martin, Christian Moraru, and Andrei Terian (eds.), Romanian Literature as World Literature, New York, Bloomsbury Academic, 2018, p. 5.

5 Andrei Terian, "Mihai Eminescu: from National Mythology to the World Pantheon", in Mircea Martin, Christian Moraru, and Andrei Terian (eds.), Romanian Literature as World Literature, p. 35.
} 
and with different cultural-political ideologies), but it certainly did not serve Eminescu's cause abroad. In addressing the issue of Eminescu's place within the world literature framework, the extremes are, on the one hand, the poet's utter encapsulation of the Romanian ethos that renders him "too Romanian" and therefore untranslatable and, on the other hand, the unmitigated belief in the poet's universality (that Lucian Boia identifies as symptomatic of the Eminescu myth). In a very interesting study entitled "A Romanian Product Refused Export: Mihai Eminescu, the National Poet", Ioana Bot summarizes the issue of the poet's exportability and identifies the main problems that occurred in the process of cultural branding. The author begs the question of

why, in spite of Romanian culture's (concrete and long-lasting) efforts to transform Eminescu into an identitary key image that is exportable and highly symbolic, "Eminescu, the Romanian national poet" does not pass the test, and, moreover, does not succeed in breaking the frontiers of a Romanian Studies specialists' circle into the Western academic environments ${ }^{6}$.

She then goes to show that the argument of untranslatability and the obsolescence allegations are put forward to make amends for the shortcomings of a faulty cultural promotion strategy.

\section{Transnational as translational}

A key-issue in addressing Eminescu's exportability problem as well as in discussing his place among the key-authors of world literature is translation, as universality does require translatability (and by that we refer not only to the possibility of being translated but also to the ability of translating). This prerequisite is, in our opinion, of paramount importance to the dissemination and reception of Mihai Eminescu's works abroad. In spite of the general anonymity that surrounds the poet's name beyond the borders of his emergence, there are numerous translations of his work that we can account for. However, even though this favourably answers the question of his translatability in terms of the possibility of rendering his texts in other languages, it does not vouch for the actual quality of translation, nor does it guarantee the efficiency of the texts' publication and dissemination abroad. In analysing the poet's exportability, Ioana Bot takes into account the translations and editions destined for publication abroad (which are, indeed, more relevant to the author's visibility than those published in his native land), the paratexts that accompany the translations (usually entailing presentations by the "media's opinion makers" and by the Romanian cultural institutions ${ }^{7}$ ), the

\footnotetext{
${ }^{6}$ Ioana Bot, "A Romanian Product Refused Export: Mihai Eminescu, the National Poet”, in Liviu Papadima, David Damrosch, Theo D'Haen (eds.), The Canonical Debate Today, Crossing Disciplinary and Cultural Boundaries, Amsterdam, Rodopi, 2011, pp. 292-293.

${ }^{7}$ Ibidem, p. 293.
} 
efficiency of the prefaces signed by foreign translators that have taken an interest in Eminescu's works as well as the problems that the author's poetry poses to translators. We can therefore observe that we are dealing with several problematic parameters.

When it comes to the issues related to the translation process itself, several factors weigh in the problem of translatability: the cultural and linguistic differences, the presupposed impossibility of translating poetry and the unique difficulties which Eminescu's texts pose to the translators (the specifics of Eminescu's poetry, generally perceived in terms of the rhyme/meter/content triad, make it appear as an insurmountable task for the English translator who often qualifies the poet's texts as untranslatable).

Another interesting argument, this time related to the visibility that the translation volumes might have with the help of foreign translators that attempted to promote the poet in their home countries, is that the effect of such endeavours is minor, for the translators dedicated to such an undertaking are, in Ioana Bot's opinion,

mediocre poets (perhaps with the exception of Iannis Ristos or Rafael Alberti), who give the impression of using this tribute to a foreign writer in order to include themselves "in the consecrating picture", without being prestigious authors in their native cultures. They practice (without exception) the encomiastic comparison, the analogy between absolute and incomparable values in themselves ${ }^{8}$.

Whereas these authors enjoy recognition in the Romanian cultural context, their activity and visibility abroad are confined to the circle of Romanian Studies, a monad of sorts as far as the foreign general public is concerned.

In an article dedicated to the issue of translating Eminescu (having as premise a somehow unrealistic and biased comparison between the Romanian poet and Shakespeare), Adrian George Săhlean, whom we can include in the category of Romanian translators of Eminescu who are living abroad (in his case the U.S), makes an interesting comment: "Eminescu, widely celebrated in Romania and by Romanians the world over, may well be the least known great national poet in the English speaking world". The issues he identifies as being responsible for this great unknown figure partly match those we presented earlier, with the difference that his commentary focuses more on the similarities between the two languages and on the expectations of the English-speaking public.

When it comes to the reception medium of the translations, he argues not only that the understanding that an English native has of Romanian folklore and the literary expression of this traditional field is superficial at best, but that this

\footnotetext{
${ }^{8}$ Ibidem, p. 295.

${ }^{9}$ Adrian George Săhlean, "Shakespeare \& Eminescu - Measure for measure", The Market for Ideas, September-October 2018, 13: http://www.themarketforideas.com/shakespeare-amp-eminescumeasure-for-measure-a163/. Accessed December 20, 2019.
} 
problem is coupled with the dwindling interest in the English-speaking world for poets of yesteryear, and with the extremely low interest by the book readership in translations and in poetry in the US.

\section{Translator typologies}

A natural follow-up of this discussion brings into focus the direct factors involved in Eminescu's translation: by whom and how.

Speaking of who translated Mihai Eminescu's work, we can easily identify three categories based on language: non-native speakers living in Romania (usually academics, University professors of Romanian Studies), non-native speakers living abroad (some of them affiliated to Universities of the English-speaking world) and native translators (who have travelled to Romania for political purposes, who have never been to Romania but who came across the poet's work or who taught in Romanian Universities as associate professors). Another distinction we can make is between professional and non-professional translators (for instance one of Eminescu's translators into English was Dimitrie Cuclin, a music conductor and a professor at the Royal Academy of Music and Dramatic Art in Bucharest).

When it comes to non-native translators (Andrei Bantaș, Leon Levițchi, Ana Cartianu, Corneliu M. Popescu, Irina Andone, I.O. Stefanovici, etc.), we must bear in mind the fact that they were mostly academics translating from their native language into a foreign one. That brings into question a level of competence that surpasses that of philological language. In that respect, we notice among the Romanian translators that are providing poetry renditions into a language other than their native tongue an unrelenting tendency to preserve the metrical parameters as well as the rhyme structures of the original (which leads Săhlean to the conclusion that "rhyming is by far the most responsible for the inaccurate approximation of Eminescu's content into English by Romanian translators. This is often not only awkward but, at times, hilarious to a native speaker" ${ }^{\prime 10}$ ), even at the risk of sacrificing meaning or of breaking grammar rules. As for the context that determined the publication of such translation volumes, we can say that Eminescu was translated a great deal during the communist regime (especially between 1960-1975), but we must take into consideration the thematic restrictions that the political climate imposed upon the translators. However, these internal translations occasioned by ideological volition are not relevant for the poet's reception abroad.

The foreign translators of Eminescu's poetry fit another picture. Their category is more diverse, since it is made up of several interesting typologies. There are, for instance, foreign translators that came into contact with Eminescu's works in an academic context, such as Roy MacGregor-Hastie or Brenda Walker (both translators of Blaga as well). The American MacGregor-Hastie (1972)

${ }^{10}$ Ibidem. 
"discovered" Eminescu in a period of increased political interest in Eastern Europe, translating him with a passionate mind. His variants, Săhlean believes, are reduced, however, to content translation of an informative nature, with no artistic claims, renouncing prosody from the start as an un-accomplishable task that didn't fit the purpose. A couple of decades later, Brenda Walker (1990) would take the same approach.

Interestingly enough, other foreign translators did not know Romanian, and used intermediaries for the content: James Moulder based his creative transpositions upon Google Translate results and upon the translations provided by Corneliu M. Popescu, Sylvia Pankhurst (1928) worked on literal translations by I. O. Stefanovici, and Brenda Walker (1990) teamed with Horia Florian Popescu.

Part II.

In the first part of our paper we have tackled theoretical issues, the general aspects of the problematics in question, in order to provide a better understanding of the premises as well as of the main framework within which our study places itself. In this second part of the paper, we attempt a more detailed incursion into the issue of Eminescu's translation into English by analysing the contexts in which his first translations appeared, who his translators were and what they had to say.

\section{A chronological incursion into Eminescu's recognition abroad (diplomats, wanderers and suffragettes)}

By far the most interesting details that do not fail to further emphasize the paradoxical discrepancy between, on the one hand, the number of translations and the interest towards the poet's work and, on the other hand, his poor visibility abroad as well as his difficult exportability, are those related to the first attempts of translating Eminescu into English. The circumstances in which these translations were coined, are, in our opinion, of a historical and cultural interest, not only circumscribed to the poet's visibility abroad but also to the way his culture is presented to a foreign readership at key-moments of its international development (The Independence War, the immediate post-war situation). Not only the early signs of the poet's recognition are of interest here, but also the particular profile of those who have taken an interest in his works.

William Beatty-Kingston - 1877(1888). British memoirist, journalist for the "Daily Telegraph" and translator, William Beatty-Kingston is, according to our research, the first translator of Eminescu's poetry into English. As war correspondent for the British press, Kingston visits Romania on several occasions, once in 1865, when he meets Alexandru Ioan Cuza, a second time in 1874 and again during the Independence War (1877-1878). From the little we could find out about him, we gather that his travels to Romania were documented in several 
volumes (Monarchs I Have Met (1886), A Journalist's Jottings (1990), A Wanderer's Notes), his knowledge of Romanian allowing him to translate poems by Eminescu and Alecsandri. We also found out that he had close ties with I.C Brătianu and Mihail Kogălniceanu and that he wrote about the Romanian political class in a book entitled Men, Cities and Events.

Among the volumes enumerated, the one that interests us most is Monarchs I Have Met for it is there he describes the exact circumstances that lead to the translation, in 1877, of one of Eminescu's poems (who was 27 years old at the time of the translation): Crăiasa din povești. In this book, dedicated to Queen Elisabeth of Romania, there is a chapter entitled "The Legend Queen" dedicated to the encounter he has with the Queen and to the impressions they have exchanged regarding the translation of Eminescu. After describing the role that the Queen plays in her country, he proceeds to describe the circumstances that led to their first encounter.

It would appear that after the Vienna Exhibition in 1873 he was in the midst of a sparring match in a cottage meant for the use of British Commissioners, when the Queen of Romania made an appearance and requested to make their acquaintance. Four years later, in 1877, not long before the commencement of the RussianTurkish hostilities, he visits the Queen in Bucharest. It is then that she expresses her wish (after hearing of his interest in Romanian literature and music) of making the Romanian ballads and folklore known to the Anglo-Saxon world with the help of native translators, using English translations and imitations. The monarch tells him that:

Though I speak and read English with ease, and can even manage to write English prose with tolerable correctness, I find the composition of verse in your language beyond my powers. But as perhaps you know, I have paraphrased a considerable number of Romanian popular poems in German, observing the original meter and rhythmical patterns as closely as I could. There is a little romantic poem of extraordinary beauty, by Eminescu, which I have just translated. I wish you would try to make an English version of it. If you will, I will copy it out for you myself, and send it to you; and your version should have a place in my own personal album ${ }^{11}$.

William Beatty-Kingston accepts this task handed to him by the Queen of Romania, not failing to warn her of the shortcomings that would surely appear as an inevitable result of the attempt to preserve the metrical parameters of the poem. $\mathrm{He}$ then proceeds to drawing a concise summary of the differences between the two languages, supported by examples. After making a brief demonstration of how Romanian works, he concludes that this type of archaic forms retained in the Romanian language facilitates versification and the economy of syllables, differentiating itself from English, which cannot limit itself to the same number of

11 William Beatty-Kingston, Monarchs I Have Met, New York, Harper \& Brothers, 1888, p. 97: https://archive.org/details/monarchsihaveme00kingoog/page/n3. Accessed December 20, 2019. 
feet. Queen Elisabeth herself confesses to Kingston the difficulties encountered during her translation attempts, the debate revolving around the sacrifices one has to make in choosing between form and content - sacrificing spontaneity and ease in favour of meter and rhythm.

William Beatty-Kingston then received Eminescu's poem along with the German translation signed by Carmen Sylva and proceeded to its translation, but found the rendition of rhyme and meter that the Queen had managed in her "admirable imitation" quite "impracticable": „I therefore thought it best, as the ballad was a singable one and its musical setting, therefore, was a consideration of primary importance in the construction of a version in a foreign idiom, to sacrifice rhyme to metre" $"$.

Charles Upton Clark - 1922. In 1922, Charles Upton Clark, an American historian and professor at Columbia University, writes a book entitled Greater Roumania $^{13}$. The writing of this book, as motivated in the preface, was occasioned both by the author's interest in the campaign of misinterpretation directed against interwar Romania (that he considered to be similar with the anti-Italian propaganda) and by an invitation he received in 1919 from the Romanian Government "to come out and observe the post-war situation on the spot"14. $\mathrm{He}$ speaks of the great ignorance of Americans towards Romania as well as of the country's role during the war, a role that was diminished in historical contemporary accounts: "Since she offers remarkable opportunities to the farsighted American capitalist and manufacturer, I have tried to make the book a trustworthy work of reference for the business man, as well as for the traveler and the student of history and literature" 15 . The aim of this undertaking is also expressed in the preface, the author confessing to his readership the desire to provide the necessary elements for a sympathetic understanding of all aspects upon which the country is based policy, ambitions, future:

I have tried to embody my deep impression of a national education, through centuries of storm and oppression, to the present marvelous development of this attractive and gifted people - how misunderstood and misinterpreted, I hope to have made clear. May the reader end sharing my conviction that Roumania has the future of Southeastern Europe in her hands, and that any Western nation will honour itself, as well as profit, by helpful association in Roumanian development ${ }^{16}$.

The table of contents suggests that the author signs a complete presentation of the country's socio-political, historical, anthropological realities, accompanied by

\footnotetext{
12 Ibidem, p. 97.

13 Charles Upton Clark, Greater Roumania, New York, Dodd, Mead and Company, 1922, https://archive.org/details/greaterroumania00clargoog/page/n10. Accessed December 20, 2019.

${ }^{14}$ Ibidem, p. v.

${ }^{15}$ Ibidem, p. vii.

${ }^{16}$ Ibidem, p. vii.
} 
pictures and titles such as: "The Plains"; "Roumanian Agriculture"; "Roumania Under the Germans"; "Roumanian Art and Architecture"; "The Roumanian Peasant Arts"; "The Roumanian Language"; "Roumanian Literature", etc.

In the chapter dedicated to the "Roumanian language", the author makes a detailed presentation of the morpho-syntactical, phonetical and etymological particularities of the lexis, taking into consideration the way in which the two languages (English and Romanian) have evolved, the way in which they were influenced by other languages (from the language families they belong to):

This survival of Latin out here in the East is most remarkable, for the Romans held Dacia only five or six generations; then all connection with the western Romance world was cut; the country was flooded with Slavs, who for centuries dominated in church and government, and with Huns and Turks; and the language was never written for over a thousand years. In consequence of all of these factors, a page of Roumanian seems very strange, even to one familiar with Italian or Portuguese, the languages that cultivated Roumanians find easiest to understand ${ }^{17}$.

Interestingly enough, in order to illustrate the phonetical and phonological considerations he makes about the Romanian language, he chooses Eminescu's poem Somnoroase păsărele, seen as representative for the `surface peculiarities` of Romanian: "I have found Eminesco's Somnoroase păsărele well adapted for that purpose in my lectures, and it furthermore illustrates to perfection the melody of the language and the rhythmic mastery of the great poet" 18 .

The translation is accompanied by a line-by-line phonetic analysis and etymological explanation that anticipates Clark's conclusion: "This must suffice to show some of the peculiarities of the language, and its genuinely Latin character, however overlaid with Slav and other embroidery. It is a fresh and virile tongue, and smacks of the open Macedonian mountains and the glens of the Carpathians" 19 .

In the $25^{\text {th }}$ chapter of the volume, dedicated to "Roumanian Literature", the author does not renounce his exhaustive approach, presenting the cultural-literary panorama in all its aspects. He speaks of Alecsandri, Eminescu and Coşbuc as of the "best Roumanian poets", inspired by Romanian folklore as well as by universal poetry. He then attempts to translate Pillat's Romanța. He appears determined to be as thorough as possible in his documentation, which makes it possible for the English reader to be presented with a full account of Romania's literary life from its beginnings. Clark speaks of translation, foreign influences, religious texts (Coresi, Dosoftei), he speaks of Costin, Neculce and Ureche's chronicles, he mentions Gheorghe Asachi, Ion Heliade Rădulescu (and the publications they have founded - Curierul Românesc and Albina Românească) and speaks of the

\footnotetext{
${ }^{17}$ Ibidem, pp. 343-344.

${ }^{18}$ Ibidem, p. 346.

${ }^{19}$ Ibidem, pp. 359-360.
} 
"pioneers" of Romanian poetry (Costache Negruzzi, Dimitrie Bolintineanu, Vasile Alecsandri) and of historians such as Nicolae Bălcescu, Mihail Kolgălniceanu, etc.

Here is the illustrative paragraph with which Clark concludes his chapter on Romanian literature:

It is true that a cruel and devastating war, followed by huge economic and political difficulties, has checked Roumanian literary expression. But this check will surely be only temporary. A people with the innate literary taste of the Roumanian peasant witness his ballads and his folk-tales - and the literary ambition of the educated Roumanian, will not long remain mute. In all the discouragement of to-day, it is nevertheless clear that Roumania stands on the threshold of a vast expansion; and this stimulus will doubtless have its effects in literature $\mathrm{also}^{20}$.

Sylvia Pankhurst - 1930. The Oxford Guide for Literature in English Translation $^{21}$ mentions the translation made, in 1930, by the suffragette E. Sylvia Pankhurst with the help of the Romanian translator I.O. Ștefanovici, published in London in $1930^{22}$. This is often thought to be the first translation of Mihai Eminescu's poetry into English. The Guide specifies that "Pankhurst discovered in Eminescu (1850-89) a kindred spirit in dislike of contemporary decadence and social injustice, and she sent her translations to her friend George Bernard Shaw". His comment in his preface to the volume, 'the translation is astonishing and outrageous: it carried me away', was suitably ambiguous" ${ }^{\prime 23}$. Even more interestingly so, Sylvia Pankhurst was a socialist feminist who was involved in the campaign for women's suffrage at the turn of the $20^{\text {th }}$ century, and who is known, amongst others, for having founded a women's organisation entitled the East London Federation of Suffragettes whose members were working class women campaigning for the right to vote and for social change in the period 1912-1920. Sylvia Pankhurst is also the daughter of Emmeline Pankhurst, co-founder of the Women's Social and Political Union, whose members were known as suffragettes.

According to the catalogue world.cat.org, this translation was edited 9 times and can be found in 79 libraries across the globe, including places such as Cambridge and Oxford University libraries, King's College, Trinity College, Royal Danish Library, Yale University Library, Library of Congress in Washington DC, etc.

In our research, we have stumbled upon some photocopies containing E. S. Pankhurst's introduction to the Eminescu translation and some documentation

\footnotetext{
${ }^{20}$ Ibidem, p. 374.

${ }^{21}$ Peter France, (ed.), The Oxford Guide for Literature in English Translation, Oxford, Oxford University Press, 2001, p. 215.

${ }_{22}$ Mihai Eminescu, Poems. Translated by Sylvia Pankhurst, I.O Ștefanovici, London, Kegan Paul, Trench, Trubner \& Co, 1930.

${ }^{23}$ Ibidem, p. 215.
} 
about M. Eminescu that date back to 1934, as well as upon several translation versions of Poor Dionis.

From what we were able to decipher from her handwriting, we present here some very interesting fragments regarding the poet's high esteem for Eminescu, coupled with a brief commentary on Emperor and Proletarian. The manuscript, numbered $308^{24}$, is actually the handwritten version of a text which appears in a 1934 volume published in Bucharest and edited by Valerian Petrescu ${ }^{25}$.

We render here the introductory part to Pankhurt's commentary on several poems by Eminescu:

Hail To Thee, Bright Spirit!

Eminescu's works are for all time. Every line of his verse and prose is a polished jewel. His themes, clothed with masterly art in the picturesque (unidentified word) of this or that time or story, are the fundamental problems of human existence which never grow old, illumined by a powerful and original intellect with arresting thoughts. The haunted melody of his enchanted strains, the magic images which teem from his prolific mind dwell long in memory. Profound emotions surge at his command. In the eternal cadences of his receding lullaby, under the limpid moonlight, in the silent woods he makes his own, always some poignant note, some plaintive murmur stirs the heart's core.

She then proceeds to a brief commentary of Călin, "the fairy legend" and continues with a more detailed description of the plot in texts such as Poor Dionis. As for Impărat şi proletar, of which Pankhurst passionately writes, we found the following remark:

Where in all literature shall we find a parallel to that magnificent epic, Emperor and Proletarian? With more than Blue-Book accuracy, yet with the true timbre of high poetry, it reveals a group of homeless lads in a tavern, inveighing against their lot, venting the sore complaint belched forth on many a thousand platforms the world over, yet sublimated by the poet's genius to a quintessence of all the resentful griefs and fervent aspirations of unhappy toilers since first the strife of class and class began.

The poet's conclusion is written in the same tone as the rest of her observations, in the form of a panegyric fragment:

Ranked among the Pessimists in his day, Eminescu is of the great Optimists, whose hope, keyed high, yearning with impatient fervor for the ascent of man, seems near despair. His is the mind of scientific habit which fronts the $[\ldots]$ of the universe untrammeled by prejudice or class, or race, or creed, illumined by a great awareness of the human heart, its grief and joy, its fear and hope broadened by that great solidarity and interest in the collective work and destiny of mankind which blots out pettiness.

\footnotetext{
${ }^{24}$ Unpublished manuscript. https://search.socialhistory.org/Record/ARCH01029/ArchiveContentList\#120. Accessed December 20, 2019.

${ }^{25}$ Valerian Petrescu, (ed.), Omagiu lui Mihai Eminescu [Homage to Mihai Eminescu], Bucharest, Editura Univers, 1934.
} 
We hail him as a thinker of his time and yet a modern among the moderns still, a lover and the preeminent interpreter of his own people, a citizen of the world.

The manuscript also contains a copy of a commemorative issue of the publication Cuvântul nostru, occasioned by commemorating 40 years from the poet's death and published in Botoşani in June 1929.

\section{Conclusion}

Our research places itself within these two concentric frameworks, the general issue of world literature and the applied case of the national literary context, and constitutes an analysis of the translation of Mihai Eminescu's poetry into English. Far from solely proposing a comparative, side-by-side study of his texts' renditions into a foreign language, the subject addresses the more complex issue of exportability (and, therefore, translatability), relevance and place (occupied within the world literature) of the most debated Romanian identity figure and myth: Mihai Eminescu-the national poet.

The study of the presence of Mihai Eminescu's works in the anglophone reception area, necessarily preceded by an analysis of idea content, seen as the point of confluence of several cultural sources, reveals that the thesis of Mihai Eminescu's texts belonging to world literature is demonstrable through at least two research angles: the first one from inside the literary text and the second one emerging outside the literary text. Once established, the operating principles of the world literature concept circumscribe two fields of analysis, multipliable at the level of their constituent elements: the literary macrocosm and microcosm.

Eminescu's texts can therefore be read as world literature through their heterogeneous nature at the level of lyrical and thematic composition (an argument demonstrable by classical Eminescology, starting with the observations made by theoreticians such as Dumitru Caracostea, Garabet Ibrăileanu, Nicolae Iorga , Titu Maiorescu, Constantin Dobrogeanu-Gherea, as well as the by the pragmatic approaches of Ioana Bot, Iulian Costache, Andrei Terian) and as a part of the network of world literature (as imagined by theorists like Damrosch, Apter, Casanova, etc).

Indeed, the translation study, although distinguishing itself by its distance from classical approaches, can thereby be considered an independent analysis, revealing, through the novelty of the approach, both the virtues of the original creation (since the comparative analysis must necessarily be preceded by plenary understanding of the original text) and the tensions inherent in the translation process. The analysis of Eminescu's work from the angle of world literature clearly benefits not only from the study of its reception in the cultural-linguistic "target" environments, but also from the careful observation of the factors involved in this translocation. 


\section{BIBLIOGRAPHY}

APTER, Emily, Against World Literature. On the Politics of Untranslatability, New York, Verso, 2013.

BEATTY-KINGSTON, William, Monarchs I Have Met, New York, Harper \& Brothers, 1888.

BLOOM, Harold, Canonul occidental. Translated by Diana Stanciu, Bucharest, Editura Univers, 1998.

BOIA, Lucian, Mihai Eminescu, românul absolut. Facerea și desfacerea unui mit [Mihai Eminescu, Absolute Romanian. The Making and Unmaking of a Myth], Bucharest, Editura Humanitas, 2015.

BOT, Ioana, "A Romanian Product Refused Export: Mihai Eminescu, the National Poet", in Liviu Papadima, David Damrosch, Theo D'Haen (eds.), The Canonical Debate Today, pp. 323-335.

BOT, Ioana, ed., ,Mihai Eminescu, poet naţional român”: istoria și anatomia unui mit cultural ["Mihai Eminescu, Romanian National Poet". The History and Anatomy of a Cultural Myth], Cluj, Editura Dacia, 2001.

BOT, Ioana, Eminescu explicat fratelui meu [Explaining Eminescu to my Brother], Bucharest, Editura Art, 2012.

CASANOVA, Pascale, The World Republic of Letters. Translated by M. B. DeBevoise, Cambridge, Harvard University Press, 2004

CLARK, Charles Upton, Greater Roumania, New York, Dodd, Mead and Company, 1922.

DAMROSCH, David, What is World Literature?, New Jersey, Princeton University Press, 2003.

EMINESCU, Mihai, Poems. Translated by Sylvia Pankhurst and I.O Ștefanovici, London, Kegan Paul, Trench, Trubner \& Co, 1930.

FRANCE, Peter (ed.), The Oxford Guide for Literature in English Translation, Oxford, Oxford University $\quad$ Press, 2001. https://books.google.ro/books/about/The_Oxford_Guide_to_Literature_in_Englis.html?id=JKTD 2B2jxA8C\&redir_esc=y. Accessed December 30, 2019.

MARTIN, Mircea, MORARU, Christian, TERIAN, Andrei (eds.), Romanian Literature as World Literature, New York, Bloomsbury Academic, 2018.

MORETTI, Franco, Grafice, hărți, arbori. Literatura văzută de departe [Graphs, Maps, Trees. Distant Reading of Literature]. Translated by Cristian Cercel, Cluj-Napoca. Preface by Andrei Terian, Cluj-Napoca, Tact, 2016.

PAPADIMA, Liviu, DAMROSCH, David, D'HAEN, Theo (eds.), The Canonical Debate Today, Crossing Disciplinary and Cultural Boundaries, Amsterdam, Rodopi, 2011.

PETRESCU, Valerian, ed., Omagiu lui Mihai Eminescu [Homage to Mihai Eminescu], Bucharest, Editura Univers, 1934

SĂHLEAN, Adrian George, "Shakespeare \& Eminescu - Measure for measure", The Market for Ideas, Sept-Oct 2018, 13, http://www.themarketforideas.com/shakespeare-amp-eminescumeasure-for-measure-a163/. Accessed December 20, 2019.

TERIAN, Andrei, "Mihai Eminescu: from National Mythology to the World Pantheon", in Mircea Martin, Christian Moraru and Andrei Terian (eds.), Romanian Literature as World Literature, pp. 35-54.

\section{THE ENGLISH TRANSLATION OF MIHAI EMINESCU'S POETRY (Abstract)}

Our research aims at reinterpreting Mihai Eminescu's work from the perspective of the world literature concept (as defined by David Damrosch, Emily Apter, Pascale Casanova), thus proposing a 
transcultural investigation of the poet's texts seen beyond the inevitably narrow horizon of local studies and within the dynamic of intertextual interaction, as well as at determining its chances of positioning with regard to the axiology of world literature by analyzing in detail the translations of Eminescu's work into English. This approach aims to highlight the way in which the poet's texts occur in a language other than the one in which they were written in order to see whether they still preserve the prestige of the "national poet" myth and the formidable propensity of suggestion that placed Eminescu's work at the centre of the aesthetic canon of Romanian literature.

Keywords: Mihai Eminescu, world literature, poetry, translation, English.

\section{TRADUCERILE ÎN ENGLEZĂ ALE POEZIEI LUI MIHAI EMINESCU (Rezumat)}

Lucrarea își propune să reinterpreteze opera lui Mihai Eminescu din perspectiva world literature (paradigmă definită de David Damrosch, Emily Apter, Pascale Casanova). Prin urmare, acest studiu propune o cercetare transculturală a textelor poetului român, care să depăşească orizontul inevitabil restrâns al studiilor locale pentru a le integra în dinamica interacțiunilor intertextuale transnaționale. Totodată, prin analiza atentă a traducerilor în engleză din opera lui Eminescu, studiul evaluează și șansele poetului român de a conta într-o dezbatere consacrată axiologiei world literature. Scopul unei astfel de abordări este și de a releva dacă textele traduse pot încă păstra prestigiul garantat de mitul „poetului național”, precum și extraordinara sugestivitate care a determinat plasarea lui Eminescu în centrul canonului estetic al literaturii române.

Cuvinte-cheie: Mihai Eminescu, world literature, poezie, traducere, engleză. 